Бабій, Ірина. «Авторські неологізми як вагомий стилетворчий компонент роману “Жовтий Князь” Василя Барки». Лінгвостилістичні студї, вип. 14, 2021, с. 7-14.

Babii, Iryna. "Author's Neologisms as a Significant Style-Creating Component in the Novel "Yellow Prince" by Vasyl Barka”. Linguostylistic Studies, iss. 14, 2021, pp. 7-14.

Удк 81'373.43=161.2

https://doi.org/10.29038/2413-0923-2021-14-7-14

\title{
АВТОРСЬКІ НЕОЛОГІЗМИ ЯК ВАГОМИЙ СТИЛЕТВОРЧИЙ КОМПОНЕНТ РОМАНУ «ЖОВТИЙ КНЯЗЬ» ВАСИЛЯ БАРКИ
}

\author{
Ірина Бабій \\ Тернопільський національний педагогічний університет імені Володимира Гнатюка, \\ Тернопіль, Україна
}

Стаття присвячена розгляду іменникових авторських неологізмів у романі «Жовтий князь» Василя Барки, зокрема, охарактеризовано їх семантику, творення та особливості функціонування. Із врахуванням семантико-граматичного підходу всі іменникові авторські неологізми поділено на три лексико-граматичні групи: назви осіб, іменники 3 конкретно-предметним значенням, іменники 3 абстрактним значенням. Найчисленнішими групами є назви осіб та абстрактні назви. Всі виявлені іменникові неолексеми утворені за традиційними словотвірними моделями, характерними для української мови. Основними способами творення неологізмів $\epsilon$ суфіксація і словоскладання. Переважна більшість неолексем - стилістично навантажені у художньому дискурсі Василя Барки.

Ключові слова: ідіостиль, неолексема, індивідуально-авторська номінація.

\section{AUTHOR'S NEOLOGISMS AS A SIGNIFICANT STYLE-CREATING COMPONENT IN THE NOVEL “YELLOW PRINCE” BY VASYL BARKA}

\section{Iryna Babii}

Volodymyr Hnatiuk Ternopil National Pedagogical University, Ternopil, Ukraine

The article highlights the issue of individual author's language creation process. The case study of the author's neologisms in the novel "Yellow Prince" by Vasyl Barka, has revealed that the writer actively introduces author's innovations into his artistic narrative. The neologisms created by the writer comprise noun, adjective, verb and adverb author's neologisms. The subject of the research is the author's noun-neologisms. The goal is to characterize their semantics, creation-model, and features of functioning. In terms of the semantic-grammatical approach, all the authorial noun-neologisms of V. Barka are divided into three lexical-grammatical groups: names of persons, nouns with concrete-subject meaning, nouns with abstract meaning. The most numerous groups of noun innovations are names of persons and abstract names. Among the identified noun neo-lexemes denoting persons, most belong to the group of nouns that characterize people by activity, their inner world, the psychological state of the characters. Among the abstract noun neo-lexemes of $\mathrm{V}$. Barka, the largest is the group of noun-names of actions, movements, processes.

(c) Бабій I., Волинський національний університет імені Лесі Українки, 2021.

Це стаття відкритого доступу на умовах CC BY-NC 4.0 
Innovations with a specific subject meaning, found in the novel "Yellow Prince", often name the objects, household items, products; names of animals, plants, fruits; premises, buildings.

All identified noun neo-lexemes are formed according to traditional word-forming models characteristic of the Ukrainian language. Productive ways of creating neo-lexemes are suffixation and word-building patterns. The vast majority of the author's noun-neologisms are stylistically loaded in the artistic discourse of Vasyl Barka. Author's nominations often contain evaluative-expressive coloring in his works of art.

The use of author's neologisms testifies to the originality of the writer's creative manner, the linguistic creativity of the author's linguistic personality. In the artistic text, innovations are an important aesthetic means of artistic representation.

Key words: idiostyle, neo-lexeme, individual author's nomination.

Вступ. Вивчення письменницького ідіостилю в останні десятиріччя набуло особливої актуальності. Посилений науковий інтерес спричинив виокремлення й активний розвиток нової лінгвістичної галузі ідіостилістики, в центрі уваги якої перебуває мовостиль письменника, образотворення, тропеїстика, індивідуальне словотворення тощо. Одним із вагомих елементів формування письменницького ідіостилю виступають авторські неологізми, які відображують світобачення і світосприйняття митця, «є специфічними знаками авторського стилю, „продуктом” складних взаємовідношень у тріаді «світ - мова - мовець» (Вокальчук 32).

Індивідуально-авторськими неологізмами вважаємо нові лексеми, які не зафіксовані в сучасних тлумачних та інших словниках мови, містять індивідуальне лексичне значення, вжиті в конкретному контексті, в якому виконують необхідну для автора художньо-естетичну роль, пов'язану 3 реалізацією письменницького задуму. Словотворення таких лексичних одиниць може бути традиційним (за відповідними словотвірними моделями, властивими мові) або оказіональним, незвичним для сучасної української мови.

Вивчення неологічної лексики відображено у працях таких відомих науковців, як: Г. Вокальчук, Н. Сологуб, С. Єрмоленко, Є. Карпіловська, Н. Клименко, Л. Кислюк, Л. Струганець, С. Богдан, О. Стишов, Ж. Колоїз, А. Мойсієнко, М. Навальна, А. Нелюба, Н. Адах, Л. Ставицька та ін.

Наше дослідження присвячене аналізу індивідуально-авторської номінації у творах відомого українського письменника Василя Барки, який активно вживав неологічну лексику. Сьогодні творчість митця більше проаналізовано з літературознавчого погляду. Мовостиль письменника поки що не $\epsilon$ повністю вивчено, тому наше дослідження $є$ актуальним. Зазначимо також, що авторські неологізми у поезї Василя Барки розглянуто у працях Г. Вокальчук «Словотворчість українських поетів XX століття» (2008р.) та Н. Адах «Авторські лексичні новотвори Василя Барки (семантико-дериваційний та лексикографічний аспекти)» (2007р.). Предметом нашого дослідження будуть авторські неологізми у прозі письменника, зокрема, в романі «Жовтий князь». 
Мета праці - охарактеризувати семантику, творення та функціонування іменникових авторських неологізмів у романі «Жовтий князь» Василя Барки, а також з'ясувати їх роль у формуванні ідіостилю письменника. Для реалізації зазначеної мети необхідно розв'язати такі завдання: виявити авторські неологізми в романі «Жовтий князь», звірити їх наявність у лексикографічних джерелах, описати семантику, творення іменникових авторських неолексем, простежити їх функціонування в парадигмі формування ідіостилю письменника.

Матеріал і методи дослідження. Матеріалом послужить роман «Жовтий князь», який науковці називають романом-катастрофою, оскільки в ньому реалістично описано українське село в період голодомору 19321933 років. Трагедію українського народу відображено через життя родини Катранників, яка «є символічним уособленням українського селянства» (Барка 21). Паризький часопис «Ле Монд» назвав роман «найкращим твором у повоєнній Європі на одну з найважчих тем».

У роботі використано метод контекстного аналізу для з'ясування семантико-граматичної природи авторського неологізму; описовий - для представлення різних тематичних груп новотворів, систематизації та узагальнення результатів; метод словотвірного та морфемного аналізу для з'ясування дериваційної структури неолексем, їх творення; метод лінгвостилістичного спостереження - для встановлення особливостей уживання і функціонування авторських неологізмів у художньому тексті, а також вияву індивідуальних ознак використання.

Результати дослідження та дискусія. Неологічний словник Василя Барки складають іменникові, прикметникові, дієслівні та прислівникові авторські неологізми. Корпус іменникових неолексем становлять три тематичні групи новотворів: назви осіб, іменники 3 конкретнопредметним значенням, іменники з абстрактним значенням.

Серед виявлених іменникових неолексем-назв осіб найбільшу групу складають іменники, які характеризують людей за діяльністю, а саме: зерносій, розмовещь, збігець, дурнороб, дармороб, поливач, кувач, давун, наганяч, хліботрус, дядько-погребник, косар-крадіжник та ін.

У сучасній українській мові продуктивними $є$ словотвірні моделі іменників-назв осіб, утворених за допомогою суфіксів -ач, -ець, -ник. Новотвори В. Барки на позначення осіб переважно утворені суфіксальним способом та складанням. Неолексеми, як правило, побудовані від дієслівних твірних основ за допомогою суфіксів -ець, -ач (-яч), -ун (збігець збігати, поливач - поливати, кувач - кувати, наганяч - наганяти, давун давити).

Назви осіб композитного типу утворені шляхом поєднання двох іменників: косар-крадіжник - косар, крадіжник, дядько-погребник - дядько, погребник. Крім чистого складання, низка іменників утворена способом складання з нульовою суфіксацією: дурноробØ - дурно робити; дарморобØдарма робити; хліботрусØ-хліб трусити. 
Більшість іменникових новотворів на позначення осіб у художньому тексті виконує номінативну роль. 3 виразним емоційно-оцінним навантаженням В. Барка вжив іменникові неолексеми хліботрус, хліботруд, хлібопрос, хлібокус, хлібонос, хліботорг, хлібокуп, хлібокрад, хлібодан, хлібобер, хлібохап в розмові двох хлопчиків у контексті: «Микола на них вимовив:

- Хліботруси!

- А ми ні: ми хліботруди, - сказав Андрій.

- В основному вірно; але хліботруди не ми з тобою, а старші. Ми хлібокуси...

- Е хлібопроси, і всякі...

- Ну, $\epsilon$... хлібоноси і хлібовози...

- Ще, зараз подумаю, є хліботорги, і хлібокупи, хлібокради. Це все...» (Барка 41-42).

Такі неолексеми утворені способом складання 3 нульовою суфіксацією шляхом поєднання іменникової і дієслівної твірної основи, а саме: хлібопросØ - хліб просити; хлібокупØ - хліб купити; хлібохапØ - хліб хапати; хлібоберØ-хліб брати і под.

Частина іменникових неолексем В. Барки характеризує зовнішній вигляд, портретні риси персонажів, наприклад: рудець, жовтар, жовтовид, рудун, які містять колірну ознаку й утворені від прикметників з колірною семантикою (рудун, рудець - рудий, жовтар - жовтий). Твірними для складних іменників великовид, скеповид виступають словосполучення великий вид, скептичний вид.

Голод, недоїдання позначився на людях. Вони ставали худими, виснаженими і нагадували тіні. Автор називає селян хліборобами-тінями: «Пролунав брязкіт віддалеки; потім посилився так, що хлібороби-тіні повернули обличчя йому назустріч» (Барка 178).

Особливістю ідіостилю Василя Барки є позначення осіб через їх предмети одягу, наприклад: бесідниця-берет, картузники («бесідницяберет додає примітку» (Барка 160); «картузники ловлять і тягнуть, як скот, всіх, що ... пустилися села» (Барка 170).

Василь Барка - майстер психологічного зображення. Письменник акцентує увагу читача на психологічному стані персонажа, мотивує його дії, вчинки через емоційне сприймання ним навколишнього, через світовідчуття, враження, почуття героїв. Частина іменникових неологізмів автора характеризує внутрішній світ, настрій персонажів: понурик, скаженець («Ти ж мучся безпровинно, бо понурик надумав з кістками взяти всіх» (Барка 35).

Авторські неолексеми В. Барки нерідко виконують виразну оцінну роль. Негативну оцінку особи передають іменники темрявці, скеповид, погубник, пекельці («Мирон Данилович відчув, як він опинився дичиною в міцніших, ніж залізо, тенетах запідозрення. I серце впало. Перед очима ті два: Остроходін і скеповид - як із примарення» (Барка 75); «Таки обступлять 
мене темрявці, - зрештою подумав Мирон Данилович. - Мене задушать, бо знаю причину» (Барка 110). Виразне оцінно-експресивне забарвлення містить іменник пекельці у контексті: «- Їзять і дивляться в двори; як бачать, що сліду нема, значить, вимерла сім'я. I вони такі веселі! Радіють, сміються, папіроски викурюють і вціляють недопалками в вікно, справжні пекельці» (Барка 177). Новотвір пекельці має прозору семантику. Як правило, більшість Баркових новотворів характеризуються прозорістю значень і мотивованістю. Темрявці - ті, хто приходить з темряви, хто несе зло, біду. Семантика неолексеми темрявці пов'язана із семантикою слів темнота, темрява, які містять символічне значення. Погубник - той, хто губить, знищує, несе смерть. Майже всі авторські неологізми Василя Барки промовисті, зрозумілі читачам.

У романі «Жовтий князь» описано трагічні події $30-\mathrm{x}$ років XX ст. Письменник уживає групу іменників-новотворів, які пов'язані або відтворюють політичну ситуацію в Україні. Частина неолексем характеризує політичні уподобання персонажів, їх роль у суспільстві, наприклад: диригент-партієщь, туз-кремлівець, привладник, приспосібник, замаскованець 3 інтернаціоналки («Сьогодні на кожного туза-кремлівця одна ферма працює. Все постачає, і птиче молоко доїть. А мельниця спільна» (Барка 132); «Не було зловтіхи ніякої, тільки чудно, бо сільські привладники йдуть nід колесо, що самі розкрутили» (Барка 194). Простежуємо, що нерідко письменник сам мотивує семантику своїх неологізмів, наприклад, у таких контекстах: «Бо це - самі чужонайняті замаскованці з інтернаціоналки; хитро влізли, щоб народ мучити: то їм загадано і то червона ціль їхня» (Барка 223); «Батько почув про покльованого і здогадався: - Приспосібник, як хорт; крикнуть: «Кусі!» - він кинеться до горла» (Барка 82). Іменник приспосібник - це «той, хто пристосовується» (приспосібник від рос. приспосабливаться).

Як було вже зазначено, творчість В. Барки відзначається психологічністю, заглибленістю письменника у внутрішній світ героя. У романі знаходимо групу авторських неологізмів, які передають психологічний стан героїв (самозасліплення, зглушення в істоті, приуява), називають психічні властивості, риси характеру (відстрах, самозвищення («Спокуса пожирає кволі душі, як незримий огонь, довівши до півбожевільного самозасліплення» (Барка 211); «Начальник обшукувачів хотів зайти в хату, але намір притьма стрінувся з такою силою відстраху перед з'явцями, що вона, мов стиснута вкрай пружина, штовхнула назад» (Барка 135).

Біль, страждання, зміни психологічного стану героя простежуємо у контекстах: «Млисті приуяви кружилися, всі розметені. Крізь майоріння відчувала: наближений морок холодною запоною обкидається, i ніде обминути» (Барка 58); «3 якоюсь, ніби дитячою, образливістю болючою вражалася душа від дрібниці, хоч одночасно, при пекучій діткливості $i$ згостреності, наставало зглушення в істоті, через що речі, надзвичайно 
важливі колись, погасли значенням для думки, мов зовсім порожні» (Барка 92). У читачів складається враження ніби сам автор переживає описані події, відчуває зміни настрою, відчуттів своїх персонажів. У цьому, власне, і вбачаємо майстерність В. Барки - письменника-психолога, письменникахудожника.

У романі «Жовтий князь» багато негативних персонажів. Письменник уживає абстрактні іменники, які називають негативні властивості, риси характеру героїв: сатанічність, каїнство, зненавидь, пекельство («Крізь окуляри Остроходіна пробіг виблиск при виразі зваги і зненавиді, який збудив селянинові в пам'яті день з дитинства» (Барка 118).

Особливістю мовотворчості В. Барки, як зазначають дослідники ідіостилю письменника, є застосування великої кількості біблійних назв, лексем релігійної тематики. Як зауважує Т. Салига, «релігійність мотивів для творчості Барки органічна. Гармонія між людиною і світом, людиною і космосом, творцем світу і джерельністю поетичного духу віршів базується якраз на біблійному грунті, на виразній релігійності» (Iсторія 175). Неолексеми сатанічність (від слова сатана), каїнство (від слова Каїн), пекельці, пекельство (пекло) мають теж сакральне походження. У контексті «...Нам зображення, - думає Мирон Данилович. - Брат брата на вилах держить; під груди вдарив і підняв, поки - смерть; поставлено малюнок, як нагадку проти каїнства, що діється, і погіршало, бо з родинами гублять» (Барка 38) письменник за допомогою неолексеми каӥнство засуджує братовбивство, зрадництво. За біблійно легендою Каїн - син Адама і Єви, який підступно вбив свого брата Авеля.

Василь Барка у «Жовтому князі» описує страшну трагедію українського народу. У передмові до роману («Від автора») письменник узагальнює: «Все разом мало вигляд якоїсь зловісної сатанічності, досі не відомої, але тепер прозначеної... Свій залізний палець він спершу наводить на віруюче селянство України, і раптом накидаються туди погубницькі сили з усього світу» (Барка 27). Сатанічність уособлює зло, біду, смерть.

При творенні абстрактних іменників-новотворів продуктивними $\epsilon$ суфікси -ість, -ств(о): сатанічність - сатанічний, каїнство - Каїн.

Серед абстрактних іменникових неолексем В. Барки найбільшу групу складають іменники-назви дій, рухів, процесів: стерплення, відпаденництво, навів, барвлення, турення, нагадка, всилення, стоянина, «nідозрострачення» та ін. («Сатинову сорочку, колись темно-синю, а тепер білясту, з рештками початкового барвлення біля коміра» (Барка 37); «Від безсоння і стоянини кволий, побрів Мирон Данилович на базар» (Барка 227).

Такі авторські абстрактні іменники, як правило, утворені суфіксальним способом від дієслівних твірних основ за допомогою суфіксів -к(a), -нн(я), -енн(я): стерплення - стерпіти, нагадка - нагадати, барвлення - барвити. 3 погляду семантики та творення цікавим $\epsilon$ іменник «підозрострачення», який можна мотивувати «страчення за підозрою». 
Частина авторських неологізмів Василя Барки характеризує фізичний стан персонажів, хворобу: пекота в шлунку, припеклість, голодність, відгик («Прокинувся я з припеклості. Щось мене давить, груди скувало $і$ дихнути не дає, як часом буває в сні...» (Барка 121); «Крім лютої голодності, терплять муку від споглядання близького хліба» (Барка 211); «Мучилась, як і раніше, від голодності, але душу опанував ще більший біль» (Барка 265).

Окрему групу становлять іменники, які характеризують природу, називають явища природи: мряковиння, сніговиння, димрява («3 посвистом і шумом погнала морозну димряву проз сиві будинки» (Барка 166-167).

Оригінальністю семантики і творення відзначаються авторські неологізми - назви місяців у контексті: «- Нема, вже нема! Тепер місяці нові - вчора нам сусід сказав. - Як по-новому грудень? - Зветься: трупень.

- Січень - як?

- Зветься: могилень.

- A mi, що попередy?

- Вересень, тепер розбоєнь, бо грабували всіх, жовтень - худень, а листопад - пухлень.

- А після січня?

- Лютий - людоїдень, березень - пустирень, квітень - чумень, а далі я забув» (Барка 231).

Такі неолексеми містять надзвичайну експресію та оцінність.

Ще одна група авторських неологізмів $\epsilon$ назвами звуків: відшум, вишум, вистукіт («Він застиг, мов прислухається до невідомого відшуму» (Барка 170); «Важкий ви стукіт розлігся по сірасто-зеленкавих бруковиках» (Барка 213). Вони утворені від дієслівних твірних основ за допомогою нульового суфікса: відшум - відшуміти, вистукітØ - вистукувати.

Іменники-новотвори з конкретно-предметним значенням, виявлені в романі «Жовтий князь», найчастіше називають:

1) предмети, побутові речі, вироби: піч-прірва, «царягряддя» («Багато селян згорало в велетенській печі-прірві, над якою стовпи диму вставали, мов над фабриками» (Барка 216));

2) назви тварин, рослин, плодів тощо: ростиння, огіреччя, звірець («...виходив, крадучися, як звірещь нічний» (Барка 300); «Заїдав скоринками і огіреччям» (Барка 270));

3) приміщення, місце, будівлі тощо: підсвіття, передбрам'я, пустош («враз бігцем винесено ручні кулемети «дегтярьови» до передбрам'я» (Барка 154); «Всюди на селі - пустош і розвалля серед злих бур'янів, звідки навіть кішка ніде не нявкне...» (Барка 281));

4) збірні назви: пташинник («Пташки ... обкидали круги над решткою саду, що обернулася в невеличкий пташинник» (Барка 289)).

Як свідчать наші спостереження, неолексеми 3 конкретнопредметним значенням в основному виконують номінативну роль, хоча зрідка - оцінно-експресивну. 
Висновки та перспективи дослідження. У результаті здійсненого аналізу індивідуально-авторських неологізмів у романі «Жовтий князь» виявлено, що Василь Барка активно вводить у свою художню оповідь новотвори (іменники, прикметники, дієслова, прислівники). Корпус іменникових авторських неолексем становлять три тематичні групи: назви осіб, іменники 3 конкретно-предметним значенням, іменники 3 абстрактним значенням. Серед виявлених іменникових неолексем на позначення осіб найбільшу групу складають іменники, які характеризують персонажів за діяльністю або передають їх психологічний стан. У романі «Жовтий князь» такі неолексеми виконують номінативну та емоційнооцінну роль. Серед абстрактних іменникових неолексем В. Барки численною $\epsilon$ група іменників-назв дій, рухів, процесів. Новотвори 3 конкретно-предметним значенням, виявлені в романі «Жовтий князь», найчастіше $\epsilon$ назвами предметів, побутових речей; тварин, рослин, плодів. Зазначимо, що вживання авторських неологізмів засвідчує оригінальність творчої манери Василя Барки, лінгвокреативність мовної особистості автора. Подальше вивчення цієї проблеми полягатиме в дослідженні неологічного словника Василя Барки, у здійсненні комплексного лінгвістичного аналізу корпусу авторських неологізмів різних частин мови у поетичному та прозовому дискурсі письменника.

\section{Список використаної літератури}

Адах, Наталія. Авторські лексичні новотвори Василя Барки (семантико-дериваційний та лексикографічний аспекти). Рівне, 2007.

Барка, Василь. Вибрані твори. Харків: Веста: Видавництво «Ранок», 2003.

Вокальчук, Галина. Словотворчість українських поетів ХХ століття. Острог, 2008.

Історія української літератури ХХ століття, за ред. В. Г. Дончика У 2 кн. Кн. 2. Київ: Либідь, 1998.

\section{References}

Adakh, Natalia. Author's lexical innovations of Vasyl Barka (semantic-derivational and lexicographic aspects). Rivne, 2007.

Barka, Vasil. Selected works. Kharkiv: Vesta: Ranok Publishing House, 2003.

Vokalchuk, Galina. Word-making of Ukrainian poets of the XX century. Ostrog, 2008.

History of Ukrainian literature of the twentieth century, edited by V. G. Donchik. 2 books. Book 2. Kyiv: Lybid, 1998. 